\title{
FRONTEIRAS DA LITERATURA BRASILEIRA CONTEMPORÂNEA: MISTURA DE GÊNEROS EM BATISMO DE SANGUE DE FREI BETTO
}

\author{
Rogério Silva Pereira
}

rogeriopereira@ufgd.edu.br

\section{INTRODUÇÃO: UMA LUZ FORA DA CAVERNA}

\footnotetext{
"Vocês compreendem, a tortura é uma coisa de tal modo horrível, que é melhor não falar dela” (FREI BETTO, 2006, p.388).

"Resta-nos a confiança na palavra evangélica de que será proclamado nos telhados o que se passa às escuras" (FREI BETTO, 2006, p. 303).
}

Como o Brasil dos anos 8o, Batismo de Sangue (BS) tateia no escuro em direção à saída da caverna da Ditadura Militar. Nesse caminho, configura-se como livro que deliberadamente mistura gêneros. Faz circular no jornalístico e no historiográfico as seivas do biográfico, do ficcional e do ensaístico. No transcurso, submete o leitor a verdadeira pletora de linguagens e de gêneros. Tal mistura faz sentido. $\mathrm{O}$ autor quer com ela produzir seiva nova para organismo novo - isto é, gênero novo para a nova esfera pública brasileira que, nos anos 8o, se ensaia por oposição à lógica violenta da Ditadura. Genero e esfera em que até os mortos podem ter voz, como veremos. 
Nesses termos, BS é pioneiro e corajoso. Publicado em 1982 é produto direto da Abertura Democrática, implementada a partir de 1979 no Brasil. Como alguns outros livros (dentre eles O que é isso companheiro?, de Fernando Gabeira) procura dar respostas ao presente democrático refletindo sobre o passado autoritário. Nele, o autor, Frei Betto, frade dominicano, ex-militante de organização clandestina, vem a público narrar história controversa: a morte do líder guerrilheiro de esquerda Carlos Marighella. Fato que envolvia, dentre outros, a cooperação de dominicanos, confrades do autor.

Era etapa nova da vida brasileira, por isso mesmo cheia de ambigüidades. A esfera pública voltava a ter prevalência, mas era ainda mero projeto. O contexto é eloqüente. De seu lado, a esquerda e as forças democráticas avaliavam suas perdas: contando mortos e desaparecidos dentre eles importantes líderes. Na esteira disso, sobreviventes, banidos e exilados arregimentavam-se para ajudar a dar rumo à redemocratização ainda mal esboçada. Por outro lado, a repressão clandestina e os torturadores, sem dar as caras, exerciam pressão sobre as chamadas forças visíveis do regime, com intenção de opor obstáculos à Abertura Democrática. Esta, por sua vez, vinha sendo fortemente encaminhada de cima para baixo: a extinção do AI-5 (1978), a Lei de Anistia (1979), o fim do bipartidarismo e a proposta de pluripartidarismo, dentre outros, foram ações promovidos pelos governos militares da época (Geisel e Figueiredo).

A situação em 1982 era delicada. A Ditadura dera passo em direção à redemocratização e a uma "harmonização de divergências" entre militares e oposição. Por isso mesmo, havia a sensação de que o quadro de repente poderia regredir ou mesmo piorar, conforme os humores da própria Ditadura. Hoje, sob perspectiva histórica, a situação pode até ser vista como se a redemocratização fosse inevitável. Com efeito, dali a três anos viria uma eleição indireta para presidente que elegeria um civil (1985), e dentro de seis anos viria uma constituição promulgada (1988). Olhado dessa perspectiva, o quadro pareceria inevitavelmente tender para as cores claras dos anos seguintes onde a liturgia democrática se tornaria rotina. Mas não era assim. Fosse à esquerda ou à direita havia expectativas de regressos e contragolpes. E não era incomum que se pensasse que a calmaria poderia ser, na verdade, prenúncio de nova tempestade. Basta recordar como exemplo do clima do momento o famoso episódio do Riocentro (um ginásio da cidade do Rio de Janeiro) em que uma bomba explodiria acidentalmente num carro, onde integrantes do exército se preparavam para detoná-la em meio a um show do Dia do trabalho (de 1981). A idéia era protestar contra as reformas institucionais 
do regime e, no limite, contribuir para um retrocesso. Ações como essas eram a possível tempestade no horizonte. No âmbito da cultura, também havia incertezas. O romance Não verás país nenhum, de Inácio de Loyola Brandão, publicado em 1981 é exemplo. Espécie de ficção cientifica distópica, o livro era profundamente pessimista ao reiterar ficcionalmente a possibilidade de continuidade indefinida da Ditadura. Sua história se passava num futuro onde as tecnocracias teriam se perenizado no poder. O enredo do livro era verossímil. Desde o Golpe Militar, sucessivos desalentos quanto à redemocratização foram se impondo. Exemplos: dissera-se em 1964 que haveria eleições em 1966 - o contragolpe de 1968, seguido do AI-5, frustrou isso; em seguida, esperava-se que a radicalização dos grupos de esquerda pusesse fim à Ditadura - os anos entre 1972 e 1975 frustraram isso com a quase erradicação dos grupos de esquerda, levada à cabo pela repressão. De fato, a esperança de que "nada será como antes”, cantada por Milton Nascimento no seu disco de 1972, já ia longe. Eram já 18 anos de uma ditadura que se prolongava desde 1964. E é por isso que os sinais de redemocratização poderiam ser, como eram, sinais ambíguos. Não Verás Pais Nenhum se apoiava nessa ambigüidade para configurar em seu enredo uma ditadura sem fim. E isso em 1981. Um ano depois, BS não encontraria quadro diferente. $\mathrm{O}$ momento era também de cautela ante as liberdades "doadas" pelo regime militar. Nesse quadro, o livro se impõe com coragem e pioneirismo. E é possível ver no Prêmio Jabuti, que BS recebe naquele ano, um reconhecimento disso, à parte, claro, seus muitos méritos.

O livro comprava uma briga. Era preciso recontar a situação em que morrera o guerrilheiro Carlos Marighella, talvez o principal líder das esquerdas clandestinas naquele momento. Marighela fora surpreendido em emboscada, e morto por agentes do DEOPS paulista, chefiados pelo delegado Sérgio Paranhos Fleury. Da emboscada participaram frades dominicanos, colaborando com o DEOPS, depois de submetidos a tortura. A esquerda e a opinião pública de modo majoritário culpavam os frades pela morte de Marighella. De algum modo, isso resvalava também sobre a ordem dos dominicanos e sobre a própria Igreja Católica (GORENDER, 1987, p. 176). Era preciso uma revisão que exumasse essa morte para reexame e reparação. Era preciso mais: recompor, no quadro de um Brasil que, dali em diante seria democrático, a imagem da participação política dos dominicanos em particular, e da Igreja Católica em geral, na luta contra a Ditadura. Nesse sentido, o livro era uma aposta num futuro democrático para o Brasil. Sua própria existência se calcava na idéia de que a vida política, feita de modo público e institucional, valeria alguma coisa nos anos que viriam. Até então, a forma de disputa 
política que parecia ter valor era aquela travada de forma privada, quase sempre violenta, levada a cabo na clandestinidade, fosse pela Ditadura fosse pela esquerda. BS apostava num novo Brasil fundado na noção de esfera pública como lugar privilegiado de disputa políticaํ․

O livro não era maniqueísta - salvo umas poucas esquematizações, vistas aqui e ali. Por outro lado, era muito crítico. Mostrava a coragem da Igreja no combate à ditadura e à tortura - mas mostrava também suas muitas leniências nesse campo. Ao lado disso, feria fundo a questão da tortura: dando nomes de torturadores, de colaboradores do regime, descrevendo em detalhes seções inteiras de tortura. Tudo isso conduzido a partir de cuidadosa pesquisa, e com um estilo de escrita que não media esforços para se comunicar com eficácia, como veremos.

A ampla documentação usada pelo autor para escrever BS faz do livro algo próximo do documentário investigativo jornalístico e historiográfico ("Fontes" no final do livro, p. 437 e ss). O capítulo "Morte, a cilada" (FREI BETTO, 2006, pp. 229-307) é o ponto alto disso. Entretanto, em momentos importantes, o tratamento que o autor dá a essas fontes é deliberadamente híbrido. $\mathrm{O}$ autor mistura gêneros e vozes nublando os referenciais do leitor. Como veremos, a estratégia é a de uma obra dramática que esgarça os limites dos gêneros, misturando documento histórico com textos que alcançam matizes ficcionais e ensaísticos.

\section{TRADUZINDO A TORTURA}

Frei Betto em BS se coloca como tradutor. Tendo vivido numa certa esfera privada, a da clandestinidade, com seus códigos e seus gêneros restritos, o autor se propõe a tarefa de traduzir esses gêneros e códigos segundo a lógica de outra esfera, a esfera pública. Nesses termos, o autor comporta-se como o bufão descrito por Bakhtin (BAKHTIN, 2002), o qual, tendo estado dentro de um espaço privado, dispõe-se a contar num outro espaço, o público, aquilo que presenciou ou viveu. Frei Betto é, como esse bufão, um indiscreto. Recusa-se a compactuar com as regras do jogo dos espaços fechados da luta clandestina e da tortura. Tendo jogado segundo as regras desse jogo, participante que foi da guerrilha, torturado que foi pelo regime, o autor é pioneiro ao negar essas regras expondo o mundo da tortura e da guerrilha. Assim, BS é contribuição

\footnotetext{
1. Aqui o conceito de "esfera pública" usado é o de Hannah Arendt. (ARENDT, 1997)
} 
para instituir nova esfera pública onde a tortura e a violência podem e devem ser relatadas, com o intuito de serem coibidas pelo simples fato de virem à luz².

Nesse sentido, devemos pensar num narrador que se esforça de diversas maneiras para traduzir em escritura a realidade que viveu. Daí a recorrência de um conjunto de metáforas e símiles, que são instrumentalizadas nesse esforço tradutório (CAMPOS, 2007).

Em outro momento, em trabalho sobre $O$ que é isso companheiro?, vimos o esforço tradutório que seu autor, Fernando Gabeira, implementava na escritura daquele livro. Como Frei Betto, Gabeira também tenta traduzir a realidade da clandestinidade para a esfera pública incipiente dos anos do pós-Anistia (1979). Nosso trabalho entrevia uma concepção de esfera pública muito definida naquele livro de Gabeira. Nessa linha, vimos que tal esfera poderia ser abstraída a partir das metáforas usadas pelo autor no texto. Por essas metáforas, fomos capazes de inferir que o autor estava escrevendo para um público muito específico: certo leitor de classe média que comprava livros. Era uma aposta: traduzir para esse leitor o que foi a tortura e a luta clandestina, tomando esse leitor como destinatário privilegiado de seu texto (PEREIRA, 2006, p. 215 e ss). Como Gabeira, Frei Betto também traduz usando metáforas. Nesse sentido, talvez seja útil pensar sobre o papel da metáfora como instrumento tradutório focando dois autores que discutem isso, Ricoeur e Haydem White. Os autores pensam a metáfora (os tropos em geral) como estando em diálogo com a conceituação. Ou na fórmula de Ricoeur que usa, por sua vez, Heidegger: "O metafórico só existe no interior da metafísica" (RICOEUR, 1983, p.387). A metáfora, nesses termos, deve ser pensada como estando em diálogo com aqueles procedimentos lógicos tais como o silogismo e a conceituação, cuja matriz remonta a Aristóteles. Hayden White usa o termo "metalógica" (WHITE, 1994, p.23) para pensar a metáfora e os tropos afins. Anteriores ou posteriores à lógica formal: essa seria a condição desses tropos.

Assim, cremos, a metáfora operando como um meta-conceito seria, pois, um instrumento de tradução recorrente em muitos momentos em BS. Nesse sentido, tomando um existente qualquer, ela inseriria esse existente em universos previamente categorizados. De fato, o que temos em BS é exatamente isso: uma realidade, a tortura, que precisa ser descrita em outros termos, para a esfera pública brasileira pós-Anistia, a qual não sabia o que era a tortura. Dois exemplos desse procedimento tomados de BS:

2. Novamente aqui estamos usando o conceito de esfera pública de H. Arendt. 
(1) "O desmaio mergulhou-o num profundo túnel que, como uma cápsula, rodopiava com ele pelos ares, conduzindo-o a um lugar muito distante, onde tudo era branco como a cor da paz" (FREI BETTO, 2006, p. 244, grifo nosso).

(2) "O cansaço diluía-se na tensão, os olhos enxergavam mil bolinhas brancas como cristais flutuantes, o raciocínio desfazia-se como bolha de sabão" (FREI BETTO, 2006, p. 252, grifo nosso).

Aqui, o desmaio e o cansaço decorrentes da tortura são traduzidos por algumas imagens: "túnel" e "cápsula", "bolinhas brancas", "cristais flutuantes", "bolha de sabão". Tudo estruturado de modo a fazer ver os efeitos da tortura a qualquer leitor, sobretudo aquele que não havia sofrido tortura. O "como" sublinhado mostra o esforço tradutório do autor: sempre preocupado em mostrar que o desmaio e o cansaço provocados pela tortura são parecidos com essa ou aquela imagem parecidos, sem serem iguais. Pelo uso do "como" o autor quer conotar que sabe que aquelas imagens são aproximações, e não identidades.

De fato, a tortura e seus efeitos, como descritos por Frei Betto, alcançam patamares muito mais profundos.

\section{MISTURANDO GÊNEROS}

Isso pode ser atestado por uma outra análise dos trechos de BS destacados acima. Em ambos podemos ver que o narrador é capaz de ir além daquilo que o gênero permite à voz narrativa. BS como sabemos é texto que se propõe ser jornalístico e historiográfico. Como a ficção literária, os gêneros jornalístico e historiográfico são em sua maioria narrativos, isto é, contam historias. Uma diferença importante entre esses gêneros e a ficção literária, contudo, é que seus textos se restringem a protocolos de objetividade que, dentre outros, vedam ao narrador acessar a interioridade dos personagens. Algo que não acontece com o texto ficcional, cuja liberdade do narrador lhe faculta esse direito (ROSENFELD, 1968). Nos trechos, como se pode ver, o narrador acessa a mente de dois personagens nos momentos imediatamente posteriores a uma das muitas seções de tortura a que são submetidos. O narrador de BS se permite relativa onisciência. Como o narrador da ficção literária, ele sabe que o personagem do trecho 1 rodopia em uma cápsula indo em direção a um ambiente branco; sabe também que o cansaço da tortura faz o personagem do trecho 2 ver bolinhas brancas e cristais, num quase delírio. O leitor é levado, assim, à mente dos personagens, num texto em que os protocolos do gênero, por princípio, não permitiriam isso. Esses 
dois personagens são frei Fernando e frei $\mathrm{Ivo}^{3}$, à época colegas de Frei Betto na ordem dos dominicanos. Dos dois, o autor ouviu depoimentos a fim de escrever BS. A onisciência do narrador de BS se explica por isso. "O narrador Frei Betto" pode entrar na mente dos personagens porque "o autor Frei Betto", provavelmente, ouviu deles a narrativa do que sentiam naquele momento. $\mathrm{O}$ texto, contudo, não traz marca nenhuma que explicite esse procedimento. É o leitor quem infere isso a partir das notas do fim do livro. Diz o autor: "Frei Fernando de Brito e Ivo Lesbaupin forneceram-me dados de suma importância não só para este capítulo [cap. IV] como para quase todos os capítulos desta obra, cuja redação iniciei em 1979" (FREI BETTO, 2006, Notas, p. 439). Frei Betto sabe o que faz. Não está cometendo nenhum erro, e sabe que está rompendo parcialmente com os protocolos dos gêneros. Escritor experiente, o autor sabia que era preciso marcar com aspas a voz de cada um dos torturados; que era preciso separar a voz do pesquisador e a do personagem. Entretanto, passa por cima disso por talvez saber que os gêneros eram camisas de força diante de suas necessidades expressivas.

Claro que Frei Betto para fazer isso se legitima no fato de ele mesmo ter sido torturado e de ser também frade dominicano. Partindo disso, toma para si o direito de falar por seus companheiros sem constrangimentos. O texto configura bem esse direito, torna-o, por assim dizer, verossímil. Curioso, contudo, é o fato de que, em outros momentos importantes, o narrador de BS, por esse dispositivo que lhe concede certa onisciência, poderia ter entrado na cabeça de muitos outros personagens para dirimir essa ou aquela dúvida. Procedimento que ele não se permite usar, mantendo rigorosamente, nesse momento, o protocolo do gênero. Um exemplo: o mistério sobre a morte de Marighela. Sabemos que em BS o autor se propõe problematizar as circunstâncias, até hoje sem esclarecimento completo, da morte de Carlos Marighella (FREI BETTO, 2006, p. 309) e do envolvimento de Frei Fernando e Frei Ivo. No livro, o acesso à verdade sobre o caso é todo feito por inferências e operações lógicas, ao modo de um investigador. Fosse uma narrativa ficcional, claro, o procedimento poderia ser o de simplesmente sondar a mente do torturador. Na esteira disso, outro exemplo: as mentes dos torturadores são caixas herméticas. A voz narrativa, tão desenvolta ao acessar a consciência dos torturados, sequer vai além de meras inferências quanto ao que pensa e sente o torturador. Inferências, aliás, que não ultrapassam o lugar comum. Exemplo disso é a recorrente referencia aos olhos de 
Freury como janela de sua psicologia, presumivelmente, perversa e cheia de ódio: "Seus olhos verdes reluziam o travo da perversidade" (FREI BETTO, 2006, p. 199), “[...] despontavam os olhos verdes [de Freury]. Pareciam cravejados de ódio" (FREI BETTO, 2006, p.239). E esse parece ser o limite para se sondar a interioridade do torturador.

BS, assim, implode a fronteira dos gêneros. Recorre à ficção e ao documental produzindo texto francamente híbrido. Por que faz isso?

\section{O CORPO E A TORTURA}

Entraram dois guardas, arrastando um rapaz vestindo apenas calção. [...] Deram-lhe um empurrão e o Corcunda recebeu-o com um chute no estômago. A vítima, muito magra, pele branca, cabelos anelados caídos à testa, olhos arregalados, gemia e pedia "pelo amor de Deus". [...] O Corcunda puxou do bolso um rolo de fios de cobre e prendeu-os à mão, na forma de chicote [...] passaram a lanhar o corpo do rapaz. Seu corpo rodopiava, saltitando entre o trio de algozes, e a pele abria-se em finos e alongados vergalhões vermelhos. Gritando, ele chora aos pulmões, manchando de sangue as mãos que tentavam segurá-lo (FREI BETTO, 2006, pp. 173-174).

O corpo tem papel preponderante em BS. Com freqüência, Frei Betto, chama a atenção para aspectos físicos de seus personagens, sejam eles torturadores ou torturados, figuras públicas ou pessoas comuns, presos políticos ou policiais. As causas disso podem estar no fato de muitos dos personagens do livro serem desconhecidos até hoje. Eram torturadores que preferiam manter suas identidades no sigilo; ou eram torturados e presos também sem nome, entrevistos aqui e ali, nessa ou naquela cela. A descrição das fisionomias e corpos parece então feita no intuito de identificar os implicados, tornando público o que então era privado. Mas o efeito principal acaba sendo o de dar corporeidade aos personagens do livro, coerente com sua proposta e seu título que fala do corpo, ou melhor, de sangue. Se há um embate entre forças de repressão e guerrilha no livro, esse embate não se dá entre nomes, subjetividades, consciências, idéias ou espíritos; se dá no nível do corpo. Corpos impotentes, amarrados, capturados, aprisionados, etc, são violados por outros corpos. Nos escuros porões da tortura clandestina, os nomes e identidades sociais são turvados. Daí, sobressaem os esquemas, enquanto as singularidades desaparecem. O que os olhos do torturado vê são corpos agindo sobre corpos. O próprio torturador tem corporeidade antes mesmo de ser nomeado. Exemplo disso é o torturador, cujo codinome é "Corcunda", mencionado no trecho acima. Dele, pouco se 
sabe no livro, a não ser suas características corporais. "Baixo, moreno, atarracado, o tronco avançado, os ombros caídos, as pernas arqueadas, o rosto riscado de rugas que davam a impressão de corte de navalha (FREI BETTO, 2006, p. 173)". O texto aqui não se furta ao estereótipo, como se a falha física pudesse evidenciar a falha moral. Mas em outros momentos, vai além e tenta sondar no físico, o espiritual, como vimos acima, no caso de Fleury.

Em qualquer caso, o corpo está com freqüência em primeiro plano, fazendo às vezes do próprio nome, numa lógica textual que procura expor tudo ao máximo, sempre nomeando aquilo que, de outro modo, persistiria permanecendo no privado.

\section{A TORTURA EXPLICITADA}

O livro se deixa lavar em sangue, com se ambicionasse "dizer tudo". O exemplo acima da extensa descrição da tortura é regra. Quando a questão é falar da tortura, BS é espécie de paroxismo que cede muito pouco à lógica da elipse, da alusão ou da sugestão. Aquela noção de que a violência beiraria os limites do indizível por ser ela mesma anterior à linguagem e à cultura não parece ser empecilho ao livro. A proposição de que a tortura seja "uma coisa de tal modo horrível, [e que por isso mesmo] é melhor não falar dela" (FREI BETTO, 2006, p.388), formulada por um juiz militar em BS, é intensamente combatida pelo livro. Nele a tortura pode e deve ser transformada em palavras.

Como pensar esse aparente excesso para descrever a tortura? Genericamente, pode-se dizer que BS ambiciona "dizer tudo", por (a) querer denunciar à esfera pública nascente as mazelas da tortura, como já vimos; (b) por uma necessidade de expressão, comum ao período (1979 em diante), necessidade que é tributária à cerrada repressão do período anterior (1964-1979). Além disso, essa aparente ambição por dizer tudo pode ainda ser creditada (c) àquela contundência, típica de uma certa literatura de impacto (CANDIDO, 20oo), que germinava no período recorde-se aqui, Rubem Fonseca. Mas talvez possamos entrever outras respostas.

BS se propõe falar, como indica seu subtítulo, "guerrilha e morte de Carlos Marighella”, sobre a vida desse guerrilheiro. Entretanto grande parte do livro é dedicada a períodos da vida de 4 frades dominicanos que eram, ao mesmo tempo, militantes clandestinos de organizações de esquerda, todos presos e torturados. São eles: Frei Betto (o autornarrador), Frei Tito, Frei Fernando e Frei Ivo. O capítulo “Tito, a paixão”, 
trata dos últimos anos da vida de Frei Tito, que acaba se suicidando, segundo o livro, em decorrência da tortura. O capítulo "Morte, A cilada", se detém sobre a prisão e a tortura dos dois últimos. As vidas do guerrilheiro assassinado e dos frades dominicanos estão, assim, profundamente entrelaçadas no livro.

A esses personagens acima aludidos, deve-se juntar um outro também muito importante, o delegado Sérgio Paranhos Fleury, chefe da emboscada que culminou na morte de Marighella; além disso, torturador de Fernando, Ivo e Tito.

O livro, assim, articula a trajetória desses personagens. No esquemático campo de forças da distensão pós-Anistia e Abertura, com Fleury já morto, Marighela é considerado o mocinho mártir. A Fleury é dado o papel de carrasco da ditadura - em qualquer caso, um vilão. Com o livro os dominicanos tentam se reposicionar nesse quadro. BS, assim, ao mesmo tempo em que torna público os paroxismos da tortura, tenta reabilitar os religiosos, inclusive o autor, frente à nova lógica da participação democrática e pública proporcionada pelo fim do AI-5, pela Abertura e pela Anistia. E o faz realizando um inventário narrativo sobre a tortura. Era preciso, pois, mostrar em profundidade e extensão o que foi a tortura para dar significado àquela tortura específica sofrida pelos dominicanos e sua posterior colaboração com a repressão.

A análise do trecho abaixo pode ser útil para compreender isso. Rico em nuances, ele é parte da longa seção de tortura de Frei Fernando, pessoalmente comandada por Freury.

No pau-de-arara, a cabeça e os ombros de Fernando pendiam para baixo, posição dilacerante para as juntas e para a coluna. Segundo consta uma invenção escravocrata aperfeiçoada pelo uso da energia elétrica.

- Como é que Marighela entra em contato com você? - indagou Freury.

Fernando não respondeu. Fios desencapados foram ligados em seu corpo e a corrente elétrica inoculada nos músculos, qual serpente mortífera desenrolando-se nas entranhas. As pontas dos fios prendiam-se às extremidades das mãos e dos pés. Rodaram a manivela do telefone de campanha, e o corpo do prisioneiro estremeceu em espasmos e dores. Multiplicavam-se as perguntas e, ante as negativas, as sentinelas do arbítrio aumentavam o ritmo da tortura. Despejavam baldes d'água no corpo da vítima, a fim de torná-lo mais sensível á intensidade das descargas elétricas.

[...] Ao cair da noite, Fernando passou a ser espancado. Erguido no pau-dearara, recebia pancadas na nuca e tapas nos ouvidos. Os dentes inferiores descarrilharam: o maxilar fora deslocado. Com socos na cabeça e no queixo, os torturadores o puseram no lugar (FREI BETTO, 2006, p.240-241).

Note-se a extensão do trecho que parece querer corresponder à própria extensão da tortura. Note-se também o detalhamento que o 
trecho faz da tortura. O que se vê acima, contudo, é apenas parte de um capítulo em que cenas semelhantes avançam por páginas e páginas. Pelo trecho, e pelo resto do capítulo, o leitor tem a nítida certeza de que Frei Fernando enfrentou terríveis provações antes de fornecer as informações que acabaram prejudicando a esquerda ou Marighella.

Como contraste, caberia recorrer a outro livro, que também fala da tortura de Frei Fernando descrita acima. Trata-se de Combate nas Trevas (publicado em 1987), de Jacob Gorender, do qual tiramos o trecho seguinte:

\footnotetext{
[...] Aplicando técnica elementar de interrogatório policial, separaram os prisioneiros e os submeteram a sessões de tortura em salas diferentes. Fleury e os oficiais da Marinha se interessavam por uma informação bem determinada: o dispositivo de ligação com Marighella. Enquanto conseguiram resistir, os frades deram pistas falsas não coincidentes. Quando, afinal, os dados de ambos coincidiram, os torturadores concluíram que haviam alcançado seu objetivo [...] (GORENDER, 1989, p.174, grifo nosso).
}

Aquilo que em BS se demora por páginas e páginas, reiterativamente, é tratado por Gorender de modo sucinto: "sessões de tortura". A economia de Gorender contrasta e dialoga com a profusão de detalhes de Frei Betto. Combate nas Trevas é, no que diz respeito à morte de Marighella, livro escrito para dar certas respostas a BS, para polemizar com este sobre a versão daquela morte. Daí talvez, o mínimo detalhe dado à tortura, tentando sugerir com isso a sua pouca importância.

Daí então uma primeira resposta para a questão levantada acima. A ênfase na nomeação e no detalhe da tortura seria produto do intenso comprometimento do autor na questão. Era preciso dar ênfase à tortura, para marcar seu alcance. Os dominicanos Fernando e Ivo deram pistas a Fleury a respeito do paradeiro de Marighella; colaboraram também na emboscada que o vitimou. Mas fizeram tudo depois de pesada tortura.

Entretanto o livro parece pressupor que "pesado", "terrível", "horrível" falam pouco. Nele, os adjetivos, e mesmo as metáforas, são insuficientes para descrever a tortura. Daí o detalhismo e, sobretudo, a extensão das descrições das seções de tortura em BS - as quais, sabese, duravam horas e horas do dia, dias seguidos. Traduzir a tortura em BS significa mais que levá-la a público: significa mostrá-la, sobretudo, como tecnologia paciente para arrancar a verdade a qualquer custo do torturado; como saber internacionalmente divulgado em cursos pela CIA (EUA) e instrumentalizado pela repressão da Ditadura; significa narrá-la em sua extensão programada e fria, em suas etapas metodologicamente pensadas, em sua capacidade de invariavelmente levar o torturado ao 
cansaço extenuante e a sucessivos desmaios, em sua capacidade de amoldar as identidades e vontades dos torturados para, enfim, obrigá-lo a falar e fazer o que o torturador quer - no limite, enxertando as vontades desse torturador na mente do torturado, como o livro diz que sucedeu a Frei Tito. Significa, nesses termos, mostrar a tortura como sacrifício tão ou mais terrível que a morte, justificando o procedimento dos dominicanos na dita colaboração com a emboscada que matou Marighella.

\section{TRADUZINDO A TORTURA}

BS de certo modo é tentativa de amplificação da voz de Frei Tito. Colega da ordem dominicana, amigo do autor, Frei Tito foi também torturado em circunstâncias semelhantes às dos demais dominicanos. Por conseqüência das seqüelas psicológicas deixadas pela tortura, o que acabou culminando em profunda depressão, Tito se suicidaria no exílio anos depois. Como vimos, o capítulo “Tito, a paixão”, relata sua tortura, levada a cabo por Sérgio Fleury - e relata também as circunstâncias de seu suicídio.

Se Frei Fernando e Frei Tito são os dominicanos que sob a mais terrível tortura (e como tantos outros) acabaram "falando"; Frei Tito é a prova da boa estirpe dos dominicanos: ele não fala - mas acaba pagando um preço alto: a depressão, a loucura e o suicídio.

A voz de Tito tem prevalência sobre a voz dos demais personagens do livro, rivalizando com a do narrador. Vimos que o narrador de BS narra as torturas de Frei Fernando e Frei Ivo, usando uma voz de narrador onisciente que invade as seções de tortura, que penetra as mentes dos torturados para saber o que sentem e pensam. Por contraste, no capítulo sobre a tortura de Tito, a voz que narra a tortura é a do próprio Tito.

Morto em 1974 na França, Tito deixou, entretanto, relatos, documentos, reportagens, cartas, fotos, poemas, etc, mais tarde coligidos por amigos. Anos depois, Frei Betto se vale disso em seu livro, para recompor a trajetória do colega morto. Tudo isso é usado, em 1982, como fonte primária e material básico para a escrita de BS. É, aliás, a base do capítulo sobre Tito. O autor, usando a documentação, dá no livro sua própria visão, reordenando o material.

Porém, em parte do capítulo, o autor traz a voz de Tito para o primeiro plano da narrativa. Nela, o torturado conta a sua própria tortura em longos trechos. É que, ainda preso em 1970, Tito redige e faz publicar na Alemanha (BS, p. 384), as sevícias que sofrera. Em 1982, Frei Beto retoma 
esse relato na íntegra e o cola no texto de BS. O resultado é complexo quando a questão é discutir qual é o gênero desse novo produto.

Uma primeira conclusão. A crueza do relato de Tito descrevendo a própria tortura parece de certa forma se amplificar em BS. A tortura explícita que circula nas veias de BS tem sua fonte naquele relato explícito de 1970, escrito por Frei Tito. É ali que Frei Betto vai buscar o pathos violento e explícito que dá movimento ao texto de BS. A impressão é que o documento bruto, o relato de frei Tito, gera sobre si um suplemento - que é próprio texto de BS. Escrito no calor da hora, esse relato de Tito serve como mote, 12 anos depois, ao livro. O suplemento que é BS dará, assim, novo fôlego ao texto de Tito. Ao mesmo tempo, dá voz a esse texto e o amplifica. E faz isso adotando a descrição da tortura como a própria denúncia dessa tortura. O procedimento de que se vale o autor tangencia o ensaio e o literário - em qualquer caso, confere ao documento bruto um sentido mais amplo do que ele teria.

O longo trecho em que o relato de Tito aparece, de mais de 10 páginas (FREI BETTO, 2006, pp. 373-382), mereceria cuidadosa análise. Mas aqui devemos nos contentar com um ou outro comentário. Vamos então a um exemplo dentre muitos que podem ser referidos.

Como dissemos, o trecho mescla a voz de Tito e a do Narrador. A certa altura, ao mesmo tempo em que o narrador fala de um tal capitão Roberto, "obcecado em difundir a Palavra" e que teria levado uma Bíblia a Tito na sua cela (FREI BETTO, 2006, p.378), o leitor ouve a voz de Tito que descreve as circunstâncias de sua tentativa de suicídio após dias e dias na prisão (FREI BETTO, 2006, p. 379). O texto desse trecho é estruturado como se fosse um diálogo entre narrador e personagem, entre Frei Betto e Tito.

O narrador fala: (1) "[...] o Novo Testamento que tu leste fora presente do capitão Roberto, crente obcecado em difundir a Palavra, sem, no entanto, reconhecer-se cúmplice da profanação sacrílega que se pratica ali dentro [do presídio] sobre os verdadeiros templos de Deus [os próprio corpos dos torturados]" (FREI BETTO, 2006, p.378, grifo nosso)

Em seguida, a fala de Tito: (2) "[...] tomei a gilete, enfiei-a com força na dobra interna do cotovelo do braço esquerdo. O corte fundo atingiu a artéria. $\mathrm{O}$ jato de sangue manchou o chão da cela. Aproximei-me da privada, apertei o braço para que o sangue jorrasse mais depressa" (FREI BETTO, 2006, p. 379, grifo nosso).

Em 1, o narrador fala a um "tu". A voz narrativa é a do autor, Frei Betto; o tu ao qual se dirige é Tito. Em 2 a voz que diz "tomei a gilete..." é a de Tito narrando sua tentativa de suicídio na prisão num intervalo das seções de tortura. A função da fala do narrador em 1 é suplementar a fala 
de Tito em 2, apresentando aspectos do contexto mais amplo da prisão de Tito que a narrativa deste não traz. A fala de Frei Betto é redigida entre 1979 e 1982; a de Tito é redigida em 1970.

O capítulo, como vimos, prossegue por ao menos 10 páginas nessa tentativa de diálogo. O resultado é patético: Tito prossegue narrando seu suplício, enquanto o narrador se dirige a ele. A fala de Tito é eloqüente, mas inerte, como se fosse a de um cadáver, uma vez que justaposta ao que diz Frei Betto, não se comunica com este, não responde às suas tentativas de interpelação. $\mathrm{O}$ tom do pretenso diálogo é de intimidade e de cumplicidade. De fato, o "diálogo" parece uma conversa entre dois amigos - sobretudo no que se refere à fala do narrador que se dirige com afeto a Tito. O uso do "tu" reforça a impressão de que ali conversam dois amigos. Frei Betto figura-se dando a impressão de estar ao lado de Tito nos seus momentos de suplício. Tito, contudo, está morto, como sabemos. Ambos os interlocutores estão separados por mais de 12 anos. Com efeito, o que os separa é a diferença entre a vida e a morte. Um quase paradoxo: estão separados, mas estão intensamente aproximados pelo texto - ainda que de modo ficcional. $\mathrm{O}$ que acaba se realizando nesse capítulo é uma utopia, a de aproximar Tito e Frei Betto, vida e morte, presente e passado. Ao mesmo tempo, deixando clara a impossibilidade dessa aproximação. Nesses termos, ao aproximar narrador e "tu", o texto realiza-se como texto "religioso", nos dois sentidos da palavra: "religare" ("religar") e "relegere" ("reler"). Religa: ao aproximar presente e passado, tempo da ditadura e tempo da redemocratização, vivo e morto. Dá ao solitário torturado o seu consolo; dá também ao vivo sua parcela de consolo por não estar (por não poder ter estado) com o morto no seu momento de suplício. Traz o morto para a esfera pública e o faz narrar sua dor. Nesse sentido, o texto é alento no mais alto grau: realiza imaginariamente a justiça na terra, uma vez que aqueles que foram injustiçados podem agora ter voz. Nesse sentido, o texto "re-liga".

E, ao mesmo tempo, "re-lê". De fato, como vimos mais acima, o texto relê a fala de Tito, suplementando-a, prolongando-a, fazendo-a reverberar mais além da cela e da câmara de tortura, tomando seu pathos como mote para produzir algo que não é aquela meia página de jornal publicado lá longe na Alemanha, mas um livro inteiro publicado no Brasil.

O produto é um esgarçamento dos gêneros para fazer ver além, para fazer o documento falar mais alto do que suas potencialidades originais poderiam deixar entrever. Os gêneros jornalístico e historiográfico, gêneros que fazem coro à modernização científica, com sua alegada pureza objetiva, parecem não servir plenamente ao novo Brasil com que Frei 
Betto sonha. Para ele é preciso fundar uma esfera pública onde também os mortos tenham voz - mas não com milagres, sejam eles católicos, umbandistas, ou outros. De fato, o autor até usa os gêneros jornalístico e historiográfico no início do livro (FREI BETTO, 2006, capítulo I, III, VI e V). Ao usá-los, o autor prova que conhece bem sua química. Mas por saber usá-los bem, Frei Betto sabe de sua limitação - e faz questão de turvar seus protocolos aqui e ali. E o faz, sobretudo, no capítulo final. Daí que, sabendo disso, encontra na alquimia de gêneros a fórmula eficaz para evocar o passado e mostrar os impasses de seu silêncio no novo Brasil contemporâneo. Essa alquimia parece advir de um gênero cuja forma parece combater o tratado objetivo e a linguagem científica e que, ao mesmo tempo, não se quer gênero teológico, dogmático ou mesmo místico - esse gênero é o ensaio.

"Com a objetivação do mundo, resultado da progressiva desmitologização, a ciência e a arte se separaram; é impossível restabelecer com um golpe de mágica uma consciência para a qual intuição e conceito, imagem e signo, constituam uma unidade" (ADORNO, 200o, p. 20). O ensaio de Frei Betto sabe disso. Não quer trazer Tito de volta, não quer mágica ou milagre. Seu texto rompe com os gêneros para melhor comunicar seus propósitos. Seu projeto de Brasil não despreza os gêneros ditos objetivos, mas quer ultrapassá-los. Daí a hibridez do texto que encontra seu ápice no ensaio final. Em BS, a escolha do ensaio como gênero dá a medida das esperanças do autor quanto a uma reconciliação entre passado e presente. Mas sublinhe-se: o autor não quer uma reconciliação simples. Não quer uma reconciliação que assuma a luta armada como doença infantil da esquerda brasileira (como Gabeira em “O que é isso companheiro?"). E não se contenta com aquela "harmonização pragmática" como a promovida pela Lei de Anistia, que implicou num pacto de esquecimento entre vivos, e que pouco toca na questão da busca da verdade (MEZAROBBA, 2004, p.29). BS realiza um ideal de História: o de que nada do que um dia aconteceu pode ser considerado perdido para a história (BENJAMIN, 1993, p. 223), nem mesmo a fala dos mortos.

O livro quer ser a amplificação da fala de Tito para melhor reabilitar Fernando, Ivo, os dominicanos e a Igreja Católica no contexto amplo do combate travado contra a Ditadura. Nesse sentido, a idéia da epigrafe do livro realiza-se inteira no texto de BS, seja para Marighella, seja para Fernando, Ivo e Tito. Seus nomes são tirados "da maldição e do silêncio" e são inscritos em outro espaço - o da redenção pelo presente. 


\section{REFERÊNCIAS BIBLIOGRÁFICAS}

ADORNO, T. W. "O ensaio como forma” In: ADORNO, T.W. Notas de Literatura I. Trad. Jorge de Almeida. São Paulo: Duas Cidades; Editora 34. 2003. p. 15-45

ARENDT, Hannah. A Condição Humana. Trad. R. Raposo. Rio de Janeiro: Forense Universidade, 1997.

BAKHTIN, M. "Funções do trapaceiro do bobo e do bufão no romance". In: Questões de Literatura e de Estética: a teoria do romance. Trad. de Aurora Fornoni Bernardini (et. alii). São Paulo, Hucitec/editora da Unesp, 2002. p. 275-281.

BENJAMIN, W. "Sobre o conceito de história”. In: W. Magia e Técnica, Arte e Política, ensaios sobre literatura e história da cultura. Trad. Sérgio Paulo Rouanet. São Paulo: Brasiliense, 1993. (Obras escolhidas v.1). p. 222-232.

BETTO, Frei. Batismo de Sangue: guerrilha e morte de Carlos Marighella. Rio de Janeiro: Rocco, 2006 [14a. edição]. . Batismo de Sangue: os dominicanos e a morte de Carlos Marighella. Rio de Janeiro: Civilização Brasileira, 1982 [3a. edição].

CAMPOS, V. L. Batismo de Sangue de Frei Betto: entre o público e o privado. Trabalho de conclusão de curso. Dourados, 2007: Curso de Letras UFGD. (Mímeo).

CANDIDO, A. "A nova narrativa”. In; A educação pela noite e outros ensaios. São Paulo: Ática, 200o. p. 199-215.

GABEIRA, Fernando. O que e isso, companheiro? Rio de janeiro: Codecri, 1981.

GORENDER, J. “Assim mataram Marighella”. In: Combate nas Trevas - A esquerda brasileira: das ilusões perdidas à luta armada. São Paulo: Ática, 1987.

PEREIRA, R. S. "Inaugurando o Brasil Contemporâneo: O que é isso companheiro?, entre o público e o privado”. In: Cerrados - revista do programa de pós-graduação em literatura - UnB. Brasília: 2006. n. 21, ano 15. p.209-217.

RICOEUR, P. “Oitavo estudo: metáfora e discurso filosófico”. In: A Metáfora viva. Trad. Joaquim Torres Costa e António M. Magalhães. Porto: Rés, 1983.

ROSENFELD, A. "Literatura e Personagem”. In: CÂNDIDO, Antônio. A personagem de ficção. São Paulo: Perspectiva, 1968. p. 9-49.

WHITE, H. Introdução. In: Trópicos do discurso: Ensaios sobre a critica da cultura. Trad. Alípio Corrêa de Franca Neto. São Paulo: Ed Univ São Paulo, 1994. 